\title{
Urban climate and heat stress: how likely is the implementation of adaptation measures in mid- latitude cities? The case of façade greening analyzed with Bayesian networks
}

\author{
Nora Sprondel ${ }^{\ddagger}$, Julie Donner ${ }^{\ddagger}$, Nicole Mahlkow ${ }^{\S}$, Johann Köppel ${ }^{\ddagger}$ \\ $\ddagger$ Technische Universität Berlin, Berlin, Germany \\ $\S$ Freie Universität Berlin, Berlin, Germany
}

Corresponding author: Nora Sprondel (nora.f.sprondel@campus.tu-berlin.de), Julie Donner (julie.donner@tuberlin.de)

\section{Academic editor: Davide Geneletti}

Received: 19 May 2016 | Accepted: 11 Nov 2016 | Published: 15 Nov 2016

Citation: Sprondel N, Donner J, Mahlkow N, Köppel J (2016) Urban climate and heat stress: how likely is the implementation of adaptation measures in mid-latitude cities? The case of façade greening analyzed with Bayesian networks. One Ecosystem 1: e9280. https://doi.org/10.3897/oneeco.1.e9280

\begin{abstract}
Background

Urban heat is a challenge for mid-latitude cities possibly aggravated by global climate change making it necessary to adapt the urban fabric. Façade greening has been identified as an important measure to adjust the building stock and new buildings to adverse climatic impacts. Yet, little is known on factors that influence implementation probabilities for adaptation measures. Therefore, we tried to figure out the driving forces and barriers for implementation of façade greening applying the methodology of Bayesian networks. The article presents the Bayesian network as an analytical system to examine the probability for the implementation of adaptation measures by including expert opinions.
\end{abstract}




\section{New information}

The results show that experts in Berlin estimate the likelihood of an implementation of façade greening under current conditions at $2 \%$. The article also examines further supportive factors that exist to raise this comparatively low value. A scenario including financial incentives from a backyard greening program raises the chances to $14 \%$. However, BN results confirm that it depends on the factor of "willingness" of involved actors and the right combination of supportive factors, as there are no regulations to fix the implementation of a façade greening legally.

\section{Keywords}

Bayesian networks, façade greening, implementation, ecosystem services, climate change adaptation, Berlin

\section{Introduction}

Impacts of global climate change, among them rising temperatures and higher frequencies of extreme events such as heat waves, are already noticeable (IPCC 2014). Adaptation is necessary and important - especially for cities (Satterthwaite 2006, McCarthy et al. 2010). Due to their distinctive features - the geometry of street canyons, the amount of heat absorbing materials, the additional anthropogenic heat, and a lower vegetation ratio - the temperatures in cities are higher than those in the surrounding countryside (Oke 1988, Kleerekoper et al. 2012). Global climate change potentially aggravates the so-called urban heat island effect (Lemonsu et al. 2015).

In the past years, most German cities have developed climate change adaptation strategies which particularly focus on measures of urban planning to tackle the impacts of urban heat (Donner et al. 2015). Overall, these adaptation strategies display a strong trend towards socalled "nature-based solutions" (Kabisch et al. 2016), "ecosystem-based adaptation" (e.g. Wamsler and Pauleit 2016) or "green infrastructure" (European Comission 2016). These concepts center around a similar goal, namely to use "biodiversity and ecosystem services as part of an overall adaptation strategy to help people and communities adapt to the negative effects of climate change at local, national, regional and global levels" (United Nations Environment Programme 2016). Main reasons for increasing attention of decisionmakers for "nature-based solutions" are their supposedly lower costs and higher durability than technology-based solutions to climate challenges (Naumann et al. 2014). The German cities' strategies recommend a variety of greening measures such as planting street trees or greening tramway tracks as well as the installation of façade greening to mitigate urban heat islands (Kappis et al. 2014, SenStadtUm 2011).

Façade greening is mentioned in 15 of the 24 German adaptation strategies as a measure to improve microclimatic conditions (Donner et al. 2015) and bears some interesting 
characteristics as an example for "nature-based solutions" to climatic challenges in cities. Façade greening renders various ecosystem services (ESS) (TEEB 2011) such as human health improvements (Tzoulas et al. 2007), new habitats for animals and plants (Bartfelder and Köhler 1987, Lundholm and Richardson 2010, Solecki and Rosenzweig 2004), noise reduction (Renterghem and Botteldooren 2009), microclimate regulation (Haase et al. 2014), filtering of particulate matter, and absorption of air pollutants (Escobedo et al. 2011, McPherson et al. 1997, Morani et al. 2011, Kuttler 2011).

In the urban context green façades are especially attractive as they are not used for other purposes, unlike most of the horizontal green and open spaces in cities. Façade greening needs very little space on the ground, thus, user pressure and user competition is unlikely to occur (Debus 2009). In Germany, no permission under planning law is needed to green façades if it does not involve public streets or listed buildings (FLL 2000). Therefore, it is a measure considered to be relatively easy to implement also by private actors. It would be possible to fix façade greening via local-land-use-plans, landscape plans with Biotope Area Factor, impact mitigation regulation, or design regulations (FLL 2000). As these ways of implementation are not commonly applied in planning practice, it is not part of this study to examine how to implement façade greening with these instruments. To realize this adaptation measure of façade greening, municipalities need to rely heavily on the initiative of homeowners and tenants (Akbari and Konopacki 2005, Mahammadzadeh et al. 2009) which is the focal point of this study.

The effectivity of façade greening with regards to mitigating urban heat has been examined by a range of case studies: It can decrease the (cooling) energy demand of a building as it weakens wind speed (Kikegawa et al. 2006, Perini et al. 2011, Mazzali et al. 2013); and the shading effect from leaves contributes to cooling façades (Cameron et al. 2014, Hoelscher et al. 2016, Hunter et al. 2014). This needs to be distinguished from another less pronounced effect of façade greening, evapotranspiration, which leads to lower temperatures between building walls and plants and raises relative humidity (Hunter et al. 2014, Hoelscher et al. 2016, Pérez et al. 2011). Kleerekoper et al. 2012 regard façade greening as one of many ways to establish vegetation in cities and ascribe a cooling effect to vegetation in general.

Some studies take a more skeptical stance to the cooling potential of green façades. They discovered only minor temperature change at buildings (Cameron et al. 2014, Jänicke et al. 2015). Bowler et al. 2010) also point out that all previous proof of the cooling effect of façade greening have been generated by single case studies and it has not been confirmed that it is solely down to the greening measure. However, skeptics do not question ecosystem services provided by green façades in general and many studies also proved that effectiveness of façade greening for climatic services can be raised under certain conditions. The cooling effect is dependent on the choice of the plants/ plant traits, e.g. number of leaf layers, the availability of water, and location/ meteorological conditions (Cameron et al. 2014, Sheweka and Mohamed 2012).

Research has shown that an implementation of climate change adaptation measures rarely occurs (e.g. Carmin et al. 2012, Wamsler et al. 2013). Barriers and incentives to the 
governance of implementing adaptation measures have mainly been identified in a qualitative way (e.g. Biesbroek et al. 2013). Actor-specific characteristics, the institutional environment, i.e. formal and informal rules that guide interaction, and the natural and socioeconomic environment have been shown to be crucial variables to explain why barrier and opportunities to implementing adaptation measures arise (Lehmann et al. 2015, Mahlkow and Donner 2016). However, an analysis is missing that combines qualitative and quantitative elements to study the interplay of factors that decide whether the implementation fails or succeeds.

Besides the number of studies confirming the ESS of façade greening, to date there has not been any research on the implementation of this particular climate change adaptation measure. This study intends to figure out probabilities for implementation success of façade greening by applying the method of Bayesian networks (BN). Initially, BNs were used to support medical diagnoses (Wang et al. 2002) for a long time the application of BN for environmental research questions has been limited (Bromley 2005). However, recently the application of $\mathrm{BN}$ has expanded and been tested for further research problems, especially with relation to water resources management (Bromley 2005, Henriksen and Barlebo 2008), environmental management linking nature, society, and economy (Uusitalo 2007), and in environmental modelling (Aguilera et al. 2011). For questions concerning the implementation probability of climate change adaptation measures, no example is known to the authors.

Therefore this study pursues the following questions:

- What are the influencing factors for the implementation of the adaptation measure of façade greening in the city of Berlin?

- How likely is the implementation, the so called success probability, for the variable of façade greening?

\section{Study Site}

The study was conducted in Berlin, the capital of Germany. It is the biggest (89,000 ha) as well as the most populated city in Germany with 3.5 million inhabitants (Statistical Office 2015). Berlin is situated in the temperate climate zone, transitioning from maritime to continental climate, with warm, mild summers and cold winters (Peel et al. 2007). Climate change projections imply a rise in temperatures of $2.5^{\circ} \mathrm{C}$ degrees by 2050 with more hot days and tropical nights (Lotze-Campen et al. 2009). $32 \%$ of the city area is covered by public green spaces and forests, while $57 \%$ of the city area of Berlin is used for settlement and transport purposes (SenStadtUm 2014). A recent study showed that the Urban Heat Island leads to a temperature difference of an average of 4 to $5 \mathrm{~K}$ during summer nights in Berlin compared to the surrounding rural areas (Fenner et al. 2014).

Berlin's climate change adaptation plan identifies neighborhoods with current and future priority needs for action against urban heat especially in the city centre. Façade greening is recommended as a suitable adaptation measure (SenStadtUm 2011). The city aims at "greening façades wherever possible" (SenStadtUm 2011: 5). Nehls et al. 2010 have 
identified a 600 ha area as potentially available for façade greening in Berlin. Those figures illustrate that theoretically an implementation of green façades could be feasible in the city of Berlin.

\section{Methods}

\section{Bayesian networks}

The study followed the guidelines of Bromley 2005, Cain 2001, Pollino and Henderson 2010 and used the software Netica in the version 5.15 of Norsys Software Corp. (Norsys 2015) for Bayesian network (BN) modelling.

Bayesian networks are analytical manifestations of real systems: Actors, planned interventions, and unchangeable parameters are displayed as Elements in a graphic model. Conditions of certain elements affect the state of other elements, which is shown by directed links between the elements. Elements that determine the state of other elements are so called Parent Elements. For single elements any number of states can be formulated and the probabilities for these states are calculated to finally gain the conditional probability of the target variable; in the present case this is shown for implementing façade greening. The final outcome is the conditional probability of the target variable, which reflects the potential to achieve the desired target state under current circumstances. This particular state is commonly referred to as the status quo.

The first step in the creation of a comprehensive BN is the development of a conceptual model of the investigated system in cooperation with experts (see Chen and Pollino 2012). Four qualitative expert interviews have been conducted to build a conceptual model for the case of implementing façade greening. Two researchers in the field of façade greening and two climate protection commissioners from different Berlin borough administrations were interviewed due to their knowledge on façade greening and their familiarity with the administration in Berlin. Uusitalo 2007 states that the quality of a BN is not negatively affected if only few experts are interviewed and only limited data is available. Interviewed experts provided information on the necessary elements for the conceptual BN model from their professional and disciplinary perspectives.

All mentioned elements were listed and arranged, a discussion of possible states of all elements followed. The intention was to display the current as well as the desired state of the elements (Chen and Pollino 2012). Elements potentially affecting the target state were integrated even if they are not yet relevant. The model creation process focused on identifying the actors and planning steps that are necessary to implement façade greening. The model was discussed with each expert and those expert discussions were thoroughly focused on the research object. The process of model creation and recognizing the defining structures can already contribute to answering the research question (Uusitalo 2007). 
The single conceptual models created by the four different experts were combined to form a conclusive and comprehensive Bayesian network (Figs 1,2). Research suggests that the network should at best be kept simple, as it can be a cognitive challenge for the experts to imagine combined probabilities using different factors (Uusitalo 2007). The assessment of probabilities can become confusing with a rising number of elements and influencing factors, potentially deteriorating the quality of answers (Cain 2001, Bromley 2005, Chen and Pollino 2012).

In a second step, a questionnaire (Suppl. material 1) has been developed and sent to the four experts to gain the probability values for the network. Different feasible scenarios for all single elements are determined by the network structure. Table 1 displays the questions posed to assess the conditional probability in an exemplary way using the element "information material". Fig. 1 demonstrates all four possible scenarios (depending on the state of the two elements of "general attitude" and "communication \& information"). Experts were asked to indicate how likely they find the realization of the scenarios in the right column. In the present case: the probability that information material reaches the target group under the given preconditions of positive/negative attitude of the person and sufficient/insufficient communication of the topic.

Table 1.

Example from the questionnaire to gain the probabilities of the element of "information material".

How do you assess these scenarios for information material to reach its targeted group using probabilities?

\begin{tabular}{|c|c|c|c|}
\hline Scenario & general attitude & Communication + Information & information material reaches targeted group \\
\hline $\mathbf{1}$ & positive & sufficient & $\%$ \\
\hline $\mathbf{2}$ & positive & insufficient & $\%$ \\
\hline $\mathbf{3}$ & negative & sufficient & $\%$ \\
\hline $\mathbf{4}$ & negative & insufficient & $\%$ \\
\hline
\end{tabular}

A conditional probability table is assigned to every element in the network linking up with other elements. These tables serve to further calculate the following probabilities, and make it possible to calculate the conditional probabilities of the target variable. The values gained for single elements, however, do not give any concrete information about the state of the target variable (Table 1).

When analyzing the returned questionnaires, difficulties lay particularly in the interpretation of different expert opinions concerning an element state's probability. How to handle diverging expert opinions within BNs has not been completely clarified. Using the arithmetic mean is one possibility; however, in some cases it is appropriate to weigh opinions depending on the expertise and work field of the expert (Cain 2001, Keith 1996). In particular, this approach is suitable if elements are specifically associated with the expert's different areas of profession. These values can be given emphasis in the calculation. The present study uses weighed values; if opinions differed too widely and a weighing process was not possible, both states were integrated into the network with a probability of $50 \%$. 
Using $50 \%$ for both states corresponds with a "no-go statement" as the probability does not trend to one or the other direction.

Finally, BNs allow for a scenario creation and studying questions of "what if?" (Bromley 2005). With the help of software, the states of single elements can virtually be made more likely or unlikely. The effect of the change in state on the target shows how relevant the element is or potentially could be (Pollino and Henderson 2010), thus what factors could influence the status quo. To display scenarios in a sufficient way, more than one element is often changed and the consequences of a combination of changes are tested (Bromley 2005).

Besides the possibilities of BNs there are some disadvantages in the methodology since the analysis relies on expert opinions and therefore contains uncertainties. The limitations of the methodology are demonstrated in detail in the Discussion section.

\section{Results}

The probability for a successful façade greening installation is determined by the elements displayed in the network. The desired state for the target variable is the implementation of green façades (which would ideally be $100 \%$ ). The likelihood of achieving this state under current circumstances is $2.03 \%$ (Fig. 1).

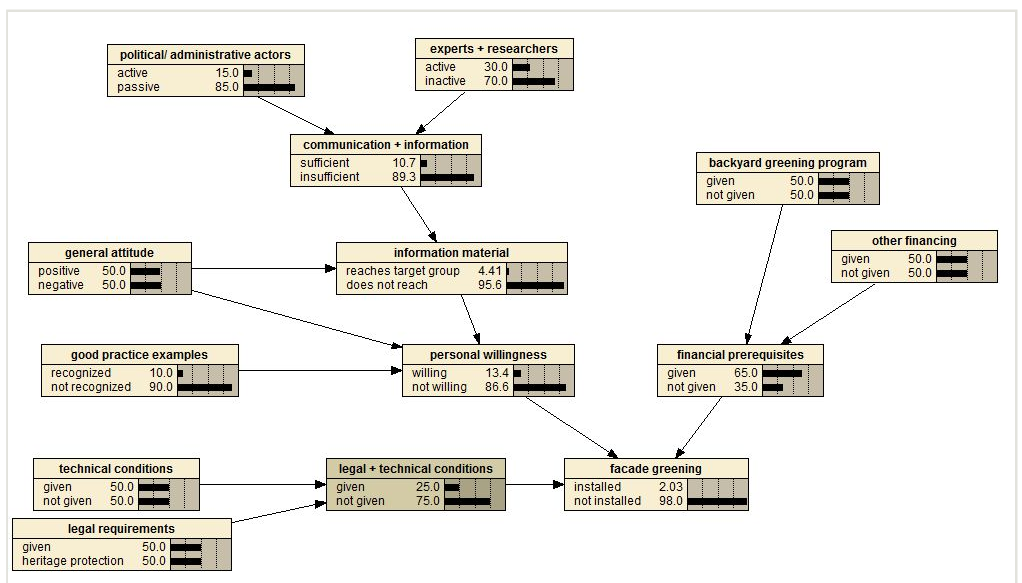

Figure 1.

Bayesian network displaying likelihood of success for façade greening in the status quo in Berlin (own figure).

According to the expert interview results, there are three main requirements to realize façade greening: Financial capacity, supportive legal/technical conditions, and willingness of involved homeowners to foster implementation. Those three preconditions are further differentiated in the network. Willingness to realize façade greening marks the beginning of 
the decision cascade; if there is no basic disposition for the implementation, the financial, legal, and technical possibilities would not be considered.

It is assumed that a communication of political/administrative actors with experts/ researchers leads to the production of information material. The assessment of how active authorities and scientific experts engage in the communication showed that authorities are responsible for distributing information among private actors; however, a lack of a scientific foundation means that the topic does not reach the political agenda. The information needs to address the target group - in this case, in particular, the homeowners. They are key actors, whose willingness is decisive for the implementation of façade greening.

Personal dispositions of homeowners towards greening their façades result mainly from their general attitude towards the subject, the available information, and the presence of good practice in the city. Legal requirements that need to be considered with regards to façade greening are, for instance, heritage protection regulations of buildings. The technical preconditions for greening a façade depend on the chosen plant species and its growth, but also the façade being free of damage and it being possible to apply stays (Köhler 2012). For the present case, legal and technical requirements are combined in the $\mathrm{BN}$ as they both are controlling and externally induced constraints.

Financial needs can be met if private capital is available, or there are financial incentives offered by the authorities, in the Berlin case either the Senate or borough administrations. A backyard greening program (providing financial incentives) can be included into the network. Such a program has been acknowledged by the experts as a strong instrument to raise the chances for a successful implementation of façade greening. The integration of a backyard greening program refers to a respective instrument of the Berlin Senate administration introduced in 1983 (Köhler and Schmidt 1997). The program is explained in detail in the discussion section.

Subsequently, the significance of every single element of the network will be analyzed by raising the desired state of the tested element to a fictitious $100 \%$ (Table 2).

Table 2.

Analysis of the meaning of single elements for façade greening.

\begin{tabular}{|c|c|c|c|}
\hline Element & $\begin{array}{l}\text { Desired state that } \\
\text { fictitiously is achieved by } \\
100 \%\end{array}$ & $\begin{array}{l}\text { Results for probability of success for } \\
\text { the target variable (Status Quo= } \\
2,03 \%)\end{array}$ & $\begin{array}{l}\text { Increase of likelihood for } \\
\text { success compared with } \\
\text { status quo }\end{array}$ \\
\hline General attitude & positive & $3,54 \%$ & $1,51 \%$ \\
\hline $\begin{array}{c}\text { Technical } \\
\text { conditions }\end{array}$ & given & $3,18 \%$ & $1,15 \%$ \\
\hline $\begin{array}{c}\text { Legal } \\
\text { requirements }\end{array}$ & given & $3,18 \%$ & $1,15 \%$ \\
\hline $\begin{array}{c}\text { Financial } \\
\text { prerequisites }\end{array}$ & given & $2,77 \%$ & $0,74 \%$ \\
\hline
\end{tabular}




\begin{tabular}{|c|c|c|c|}
\hline $\begin{array}{c}\text { Backyard greening } \\
\text { program }\end{array}$ & given & $2,77 \%$ & $0,74 \%$ \\
\hline Good practice & recognized & $2,55 \%$ & $0,52 \%$ \\
\hline $\begin{array}{c}\text { Experts and } \\
\text { researchers }\end{array}$ & active & $2,04 \%$ & $0,01 \%$ \\
\hline Authorities & active & $2,04 \%$ & $0,01 \%$ \\
\hline
\end{tabular}

A 'positive general attitude' towards façade greening turned out to be the most influential element of the network. A virtual increase of the element to $100 \%$ raises the probability for success by $1.51 \%$ to $3.54 \%$, if all other states stay the same. The general attitude of actors is a consequence of one's upbringing, education, and the social environment, becoming influential to a certain extent. Examining the results in more detail reveals that none of the elements, if they are changed individually, have a decisive effect on the implementation of façade greening. A more detailed conclusion, which elements are worth investing in, can in this case not be drawn.

In addition, an even further increase of success probability can be achieved by combining various changes in elements. To do so, a preferably realistic scenario has been developed by including the backyard greening program (Fig. 2).

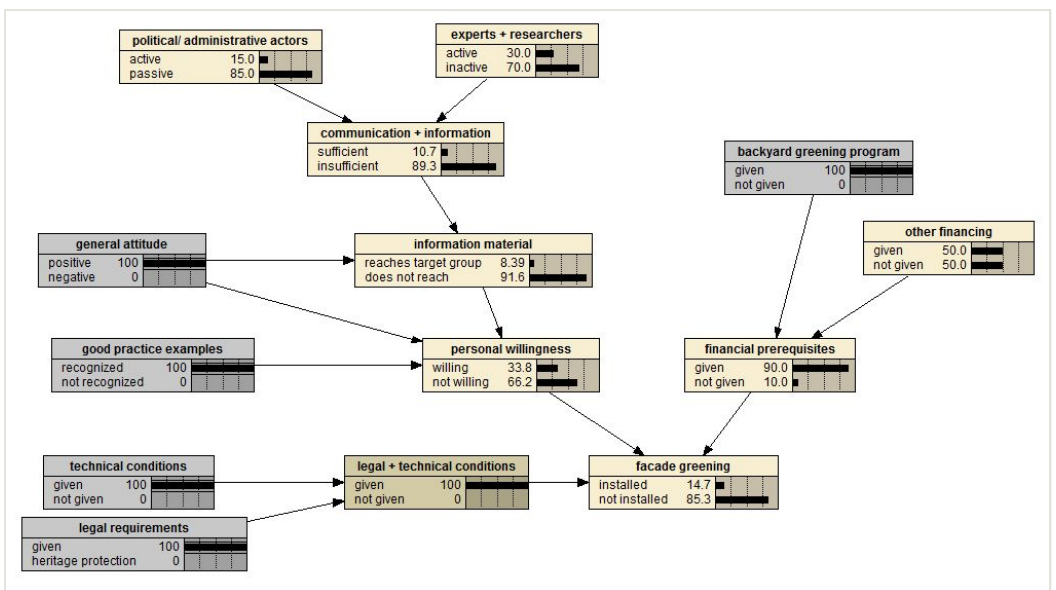

Figure 2.

Bayesian network for the implementation of façade greening with a backyard greening program and further assumptions. The altered elements are displayed in grey color (own figure).

In this scenario, façade greening is implemented at a probability rate of $14.7 \%$. On a fictitious level, a backyard greening program can be introduced and other requirements that homeowners need to make use of it can be assumed to be fulfilled: A positive attitude; open-mindedness towards 'good practice' of façade greening in the city, and also that the façade qualifies technically and legally for installing greening measures. The result shows 
that even if all necessary requirements are given, it does not lead to a $100 \%$ chance for implementation.

The question remains what reasons there are for low expectations concerning the probability for implementation of façade greening. Experts expressed further ideas in the interviews, the most frequently mentioned was that façade greening is not likely to be implemented as long as it is not financially worthwhile or obligatory. These requirements cannot be fulfilled by a backyard greening program, as greening does not pay off economically. Nevertheless, a backyard program would have benefits for the implementation probability.

Moreover, the assumption was stated that as long as a definite confirmation for the suitability of façade greening for climate change adaptation purposes is missing, authorities will not actively pursue the implementation of façade greening beyond the no-regret approach (4 oral). Another reason could be that green roofs are a more widely-known measure (Köhler 2008); with homeowners installing them, they get an accessible roof garden and therefore receive direct benefits. Furthermore, the political focus has strongly been on $\mathrm{CO}_{2}$ reduction measures such as energy efficiency and isolation in buildings (Donner et al. 2015; 3 oral).

The question remains how the network can be influenced by elements that have no parents. Within the chosen scope of analysis they cannot be influenced. However, with other available means and opportunities beyond the ones suggested in the network, those elements can be subject to change, too. This is applicable, for example, if there is a change in the elements of technical and legal compliance. Different approaches for action can be derived from fictitious scenarios including these elements. For instance, this could include the construction of future houses in a way that façade greening can be fitted retrospectively; therefore, $100 \%$ of all new buildings would be suitable for façade greening purposes. The same holds true for the legal eligibility of façades. A change in heritage protection laws, for example, could increase façade greening chances as more façades would be legally eligible.

\section{Discussion}

Previous studies stress that there are only few adaptation processes which have reached implementation (see Carmin et al. 2012, Moser and Ekstrom 2010, Wamsler et al. 2013). This study also finds low implementation prospects for the adaptation measure of façade greening. The current constellation of factors identified to be decisive for the implementation of façade greening in Berlin shows only a very low probability value $(2 \%)$. In the first instance the result suggests that decision-makers need to consider if this adaptation measure is a suitable option. Other measures might be more successful with regards to their implementation prospects in the current local political landscape.

Yet, the study identified several factors that play an important role for the implementation of green façades, which mostly also play a role within the field of adaptation planning and 
governance in general (e.g. Biesbroek et al. 2013, Mahlkow and Donner 2016, Moser and Ekstrom 2010). The BN analysis, however, allows for ranking the influence of each of the factors on the outcome. In the case of façade greening the "general attitude" of determinant actors is of outmost importance, while financial prerequisites, legal and technical conditions also have an influence on the decision to install green façades. These findings show the necessity to identify instruments and build institutional structures that help to make the installation of façade greening more independent from actor preferences.

Many authors have found similar factors to inhibit the implementation of climate change adaptation. Lehmann et al. 2015, for example, showed the need for financial support and political will. Appropriate incentives need to be set by the government. However, these studies do not provide an insight into the actual influence such incentives can have on the implementation of measures. The BN analysis can display different scenarios which raise the probability for green façade installation. The influence of enabling policy instruments (Bulkeley and Kern 2006) could be shown in one scenario, which can be considered realistic (Fig. 2). BN allowed to virtually study the impacts of a "backyard greening program" along with other requirements and could be identified as an incentive to significantly raise the implementation probability.

While the network does not give an insight into the configuration of different elements integrated into the $\mathrm{BN}$ such as the backyard greening program, their qualitative features are of importance to underline the plausibility of the BN results. These features can be singled out in the expert interviews used for the BN. For façade greening implementation the experts referred to a program that was initiated by the Berlin Senate Administration and has been in place between 1983 and 1995. The state budget covered costs for the materials to green the grey backyards of Berlin's tenements, whereas the residents had to do the gardening work, including greening roofs, façades, and backyards (Wrozlaw 1997). Without the impulse and the material incentives set by the program, residents would not have considered or realized greening measures in most backyards (ibid.). During its twelve years running time, the program helped to green $32,475,000$ ha of façades in Berlin (Köhler and Schmidt 1997). Based on its success, it seems valid to call for the (re-)initiation of a similar program; especially as an implementation of façade greening implies more than just positive effects for the climatic situation in a city (Albers et al. 2015, SenStadtUm 2011).

For studying the implementation of adaptation measures, developing Bayesian networks offers the advantage of identifying the impact single elements have on solving the policy problem of implementation, moreover, applying scenario analysis for policy problems that are riddled with uncertainty, complexity and controversy can provide important information for decision-makers (Mees et al. 2014). Probability values are often used to measure uncertainties, and therefore are an opportunity to approach topics previously characterized by a lack of empirical data (Morgan and Henrion 1990, Uusitalo 2007). The innovative aspect of the study is that the factors influencing the implementation of very specific adaptation measures as façade greening can be identified, as well as linked with probabilistic values which shows their conditional relation. 
Besides the strengths some methodical features of Bayesian networks need to be born in mind with regards to the study of façade greening. The displayed network can only be a highly simplified display of the determining factors for the implementation of façade greening. Due to its exemplary nature, the network might miss certain aspects or might not differentiate others thoroughly enough; thus, it can depict reality only in a fragmentary way (Morgan and Henrion 1990). Uncertainties with regards to model creation reflect a missing consensus of interviewed experts on links between elements and dependence of elements on each other (ibid.). Moreover, it can be expected that expert opinions about the perception of the implementation of façade greening differ as every person develops their own notion of the likelihood of some event to occur according to their own knowledge and expertise (Chen and Pollino 2012, Morgan and Henrion 1990). Uusitalo 2007 points to difficulties, which result from creating BNs with expert knowledge: It is very uncommon for most interviewees to express their knowledge in the form of probability values. It is apparent that experts do not categorize their knowledge into probability values, but they are only demanded to do so in the course of the survey (Morgan and Henrion 1990). Expert opinions may be erroneous and only an approximation of reality, but they are better than "no data" and still the best available possibility to approach certain questions (Uusitalo 2007). Hence the final result, the probability of the target variable, cannot be considered an absolute number, but displays only a tendency. To gain exact results and prognosis, BNs cannot be the method of choice (Chen and Pollino 2012). However, they can be a valuable instrument to assess the influence of different factors on the implementation of adaptation measures, especially when they involve the engagement of private actors in the building stock such as façade greening, and can therefore inform decision-makers on what pathways to stress to raise implementation success.

\section{Conclusion}

This study deals with the supportive factors for the implementation success of façade greening by using the Bayesian networks $(\mathrm{BN})$ method.

Façade greening is one suitable way to establish vegetation in cities despite the development pressure. Ecosystem services gained by urban green have been known for a long time, but implementation of greening devices such as green façades often fails. The $\mathrm{BN}$ analysis confirmed that it is not a measure that is implemented willingly, even if requirements that experts identify as necessary seem to be given. The result leads to the assumption that the promotion of other adaptation measures might be of greater success. However, enabling policy instruments such as a backyard greening program can raise the prospect of implementation.

The paper shows BNs to be useful tools to examine various factors and their probabilistic influence on the implementation of climate change adaptation measures such as green façades. Studying the probability of successful implementation of other climate change adaptation measures is a noteworthy follow-up research. Moreover, comparisons with other 
German cities with more financial means at their command than the city of Berlin could be interesting.

\section{Oral references}

[1] Research project UCaHS (oral): Interview on June 03, 2015.

[2] Professor for landscape architecture (oral): Interview on June 25, 2015.

[3] Climate protection manager borough administration (oral): Interview on June 02, 2015.

[4] Climate protection manager borough administration (oral): Interview on June 08, 2015.

Wrozlaw, 1997: Vortragstext zu einem Vortrag über das Hofbegrünungsprogramm Berlin [presentation about the backyard greening program].

\section{Acknowledgements}

The study was part of the Research Unit 1736 "Urban Climate and Heat Stress in midlatitude cities in view of climate change" (www.UCaHS.org) funded by the German Research Foundation (DFG) (KO 2952/2-1; SCHR 1254/2-1). The authors thank the anonymous reviewers and all experts for their willingness to share their knowledge with us.

\section{Grant title}

DFG Research Unit 1736

UCaHS - Urban Climate and Heat Stress in mid-latitude cities in view of climate change

\section{Ethics and security}

None

\section{Author contributions}

All authors have approved the manuscript and agree with its submission to One Ecosystem.

\section{Conflicts of interest}

I certify that there is no actual or potential conflict of interest in relation to this article. 


\section{References}

- $\quad$ Aguilera PA, Fernandez A, Fernandez R, Rumi R, Salmeron A (2011) Bayesian network in environmental modelling. Envrionmental Modelling \& Software 26: 1376-1388. https:// doi.org/10.1016/j.envsoft.2011.06.004.

- $\quad$ Akbari H, Konopacki S (2005) Calculating Energy-Saving Potentials of Heat-Island Reduction Strategies. Energy Policy 33: 721-756. https://doi.org/10.1016/ j.enpol.2003.10.001.

- $\quad$ Albers RA, Bosch PR, Blocken B, vanDobbelsteen AA, vanHove LW, Spit TJ (2015) Overview of challenges and achievements in the climate adaptation of cities and in the Climate Proof Cities program. Building and Environment 83: 1-10. https:// doi.org/10.1016/j.buildenv.2014.09.006.

- $\quad$ Bartfelder F, Köhler M (1987) Experimentelle Untersuchungen zur Funktion von Fassadenbegrünungen. [Experimental studies on the function of façade greening]. Förderprogramm der FU Berlin für junge Wissenschaftler, Berlin, 612 pp.

- $\quad$ Biesbroek R, Klostermann J, Termeer C, Kabat P (2013) On the nature of barriers to climate change adaptation. Regional Environmental Change 13: 1119-1129. https:// doi.org/10.1007/s10113-013-0421-y

- $\quad$ Bowler DE, Buyung-Ali L, Knight TM, Pullin AS (2010) Urban greening to cool towns and cities: A systematic review of the empirical evidence. Landscape and Urban Planning 97: 147-155. https://doi.org/10.1016/j.landurbplan.2010.05.006.

- Bromley J (2005) Guidelines for the use of Bayesian networks as a participatory tool for Water Resource Management. Based on the results of the MERIT project. Center for Ecology and Hydrology Wallingford 1: 1-118.

- $\quad$ Bulkeley H, Kern L (2006) Local government and climate change governance in the UK and Germany. Urban Studies 43: 2237-2259. https:// doi.org/10.1080/00420980600936491

- Cain J (2001) Planning improvements in natural resources management, Guidelines for using Bayesian networks to support the planning and management of development programmes in the water sector and beyond. Center for Ecology and Hydrology 1: 1-124.

- Cameron RW, Taylor JE, Emmett MR (2014) What's "cool" in the world of green façades? How plant choice influences the cooling properties of green walls. Building and Environment 73: 198-207. https://doi.org/10.1016/j.buildenv.2013.12.005.

- $\quad$ Carmin J, Nadkarni N, Rhie C (2012) Progress and Challenges in Urban Climate Adaptation Planning: Results of a Global Survey. Massachusetts Institute of Technology MIT.

- $\quad$ Chen SH, Pollino CA (2012) Good practice in Bayesian Network Modelling. Environmental Modelling \& Software 37: 134-145. https://doi.org/10.1016/ j.envsoft.2012.03.012.

- Debus U (2009) Vertikale Flächenpotenziale zur Biomasseproduktion im urbanen Raum - Beispiel Berlin. [Potential of vertical land for biomass production in urban areas - e.g. Berlin]. TU Berlin, ? pp.

- Donner J, Müller JM, Köppel J (2015) Urban Heat: Towards Adapted German Cities? Journal of Environmental Assessment Policy and Management 17 (2): 1-17. https:// doi.org/10.1142/S1464333215500209. 
- $\quad$ Escobedo FJ, Kroeger T, Wagner JE (2011) Urban forests and pollution mitigation: analyzing ecosystem services and disservices. Environmental Pollution 8-9: 2078-2087. https://doi.org/10.1016/i.envpol.2011.01.010.

- European Comission (2016) Supporting the Implementation of Green Infrastructure. Final Report. European Commission, Directorate-General for the Environment. http:// ec.europa.eu/environment/nature/ecosystems/docs/green infrastructures/G1\%20Final\% 20Report.pdf. Accession date: 20161007.

- $\quad$ Fenner D, Meier F, Scherer D, Polze A (2014) Spatial and temporal air temperature variability in Berlin, Germany, during the years 2001-2010. Urban Climate 10 (2): 308-331. https://doi.org/10.1016/j.uclim.2014.02.004

- $\quad$ FLL (2000) Richtlinie für die Planung, Ausführung und Pflege von Fassadenbegrünungen mit Kletterpflanzen. [Guideline for planning, construction and maintenance of façade greenings]. Forschungsgesellschaft Landschaftsentwicklung Landschaftsbau, $54 \mathrm{pp}$.

- Haase D, Larondelle N, Andersson E, Artmann M, Borgström S, Breuste J, GomezBaggethun E, Gren Å, Hamstead Z, Hansen R, Kabisch N, Kremer P, Langemeyer J, Rall EL, McPhearson T, Pauleit S, Qureshi S, Schwarz N, Voigt A, Wurster D, Elmqvist T (2014) A Quantitative Review of Urban Ecosystem Service Assessments: Concepts, Models, and Implementation. AMBIO 43 (4): 413-433. https://doi.org/10.1007/ s13280-014-0504-0

- Henriksen HJ, Barlebo HC (2008) Reflections on the use of Bayesian belief networks for adaptive management. Journal of Environmental Management 88 (4): 1025-1036. https://doi.org/10.1016/i.jenvman.2007.05.009

- Hoelscher M, Nehls T, Jänicke B, Wessolek G (2016) Quantifying cooling effects of facade greening: Shading, transpiration and insulation. Energy and Buildings 114: 283-290. https://doi.org/10.1016/j.enbuild.2015.06.047

- Hunter A, Williams NG, Rayner J, Aye L, Hes D, Livesley S (2014) Quantifying the thermal performance of green façades: A critical review. Ecological Engineering 63: 102-113. https://doi.org/10.1016/i.ecoleng.2013.12.021

- IPCC (2014) Climate Change 2014 Synthesis Report. http://www.ipcc.ch/report/ar5/syr/. Accession date: 20151218 .

- Jänicke B, Meier F, Hoelscher M, Scherer D (2015) Evaluating the Effects of Façade Greening on Human Bioclimate in a Complex Urban Environment. Advances in Meteorology 2015: 1-15. https://doi.org/10.1155/2015/747259

- Kabisch N, Frantzeskaki N, Pauleit S, Naumann S, Davis M, Artmann M, Haase D, Knapp S, Korn H, Stadler J, Zaunberger K, Bonn A (2016) Nature-based solutions to climate change mitigation and adaptation in urban areas: perspectives on indicators, knowledge gaps, barriers, and opportunities for action. Ecology and Society 21 (2): . https://doi.org/10.5751/ES-08373-210239

- Kappis C, Schreiter H, Reichenbacher K (2014) Handbuch Gleisbegrünung- Planung Ausführung Pflege. [Manual for green tracks - Planning Implementation Maintenance]. Eurailpress, Hamburg, $184 \mathrm{pp}$.

- Keith D (1996) When is it appropriate to combine expert judgments? Climatic Change 33 (2): 139-143. https://doi.org/10.1007/bf00140244

- $\quad$ Kikegawa Y, Genchi Y, Kondo H, Hanaki K (2006) Impacts of city-block-scale countermeasures against urban heat-island phenomena upon a building's energy- 
consumption for air-conditioning. Applied Energy 83 (6): 649-668. https:// doi.org/10.1016/j.apenergy.2005.06.001

- Kleerekoper L, Esch Mv, Salcedo TB (2012) How to make a city climate-proof, addressing the urban heat island effect. Resources, Conservation and Recycling 64: 30-38. https://doi.org/10.1016/j.resconrec.2011.06.004

- Köhler M (2008) Green facades—a view back and some visions. Urban Ecosystems 11 (4): 423-436. https://doi.org/10.1007/s11252-008-0063-x

- Köhler M (Ed.) (2012) Handbuch Bauwerksbegrünung. Planung - Konstruktion Ausführung. [Building green, planning - construction - implementation]. Rudolf Müller Verlag, Köln, 250 pp.

- Köhler M, Schmidt M (1997) Green backyard-, façades and roofs - A central component of urban ecology. Twelve years of experience with a greening utopia.

Landschaftsentwicklung und Umweltforschung - Schriftenreihe im Fachbereich Umwelt und Gesellschaft Nr. 105.

- Kuttler W (2011) Climate Change in urban areas. Part 2. http://www.enveurope.com/ content/pdf/2190-4715-23-21.pdf. Accession date: 2016126.

- $\quad$ Lehmann P, Brenck M, Gebhardt O, Schaller S, Süßbauer E (2015) Barriers and opportunities fur urban adaptation planning: analytical framework and evidence from cities in Latin America and Germany. Mitigation and Adaptation Strategies to Global Change 20: 75-97. https://doi.org/10.1007/s11027-013-9480-0

- Lemonsu A, Viguié V, Daniel M, Masson V (2015) Vulnerability to heat waves: Impact of urban expansion scenarios on urban heat island and heat stress in Paris (France). Urban Climate 14: 586-605. https://doi.org/10.1016/i.uclim.2015.10.007

- $\quad$ Lotze-Campen H, Claussen L, Dosch A, Noleppa S, Rock J, Schuler J, Uckert G (2009) Climate Change and the cultural landscape of Berlin. edited by Senate Department for Urban Development Berlin, Berliner Stadtgüter GmbH, Berliner Forsten, Joint Spatial Planning Department Berlin-Brandenburg 2009.

- $\quad$ Lundholm J, Richardson P (2010) MINI-REVIEW: Habitat analogues for reconciliation ecology in urban and industrial environments. Journal of Applied Ecology 47 (5): 966-975. https://doi.org/10.1111/1.1365-2664.2010.01857.x

- Mahammadzadeh M, Biebeler H, Bardt H (Eds) (2009) Klimaschutz und Anpassung an die Klimafolgen-Strategien, Maßnahmen und Anwendungsbeispiele. [Mitigation and adaptation to climate change, measures and implementation examples]. IW Medien, Köln, 310 pp.

- Mahlkow N, Donner J (2016) From Planning to IMplementation? The Role of Climate Change Adaptation PLans to Tackle Heat Stress. A Case Study of Berlin, Germany. Journal of Planning Education and Research 1-12 https:// doi.org/10.1177/0739456X16664787

- Mazzali U, Peron F, Romagnoni P, Pulselli R, Bastianoni S (2013) Experimental investigation on the energy performance of Living Walls in a temperate climate. Building and Environment 64: 57-66. https://doi.org/10.1016/i.buildenv.2013.03.005

- McCarthy MP, Best MJ, Betts RA (2010) climate change in cities due to global warming and urban effects. Geophysical research letters 37 (9): 1-5. https://

doi.org/10.1029/2010GL042845.

- McPherson EG, Nowak D, Heisler G, Grimmond S, Souch C, Grant R, Rowntree R (1997) Quantifying urban forest structure, function, and value: the Chicago Urban Forest 
Climate Project. Urban Ecosystems 1 (1): 49-61. https://doi.org/10.1023/ a:1014350822458

- Mees HL, Dijk J, van Soest D, Driessen PP, van Rijswick MH, Runhaar H (2014) A Method for the Deliberate and Deliberative Selection of Policy Instrument Mixes for Climate Change Adaptation. Ecology and Society 19 (2): . https://doi.org/10.5751/ ES-06639-190258

- Morani A, Nowak D, Hirabayashi S, Calfapietra C (2011) How to select the best tree planting locations to enhance air pollution removal in the MillionTreesNYC initiative. Environmental Pollution 159 (5): 1040-1047. https://doi.org/10.1016/ j.envpol.2010.11.022

- Morgan MG, Henrion M (1990) Uncertainty. A Guide to Dealing with Uncertainty in Quantitative Risk and Policy Analysis. Cambridge University Press, Cambridge, 331 pp.

- Moser SC, Ekstrom JA (2010) A framework to diagnose barriers to climate change adaptation. PNAS 107 (51): 22026-22031. https://doi.org/10.1073/pnas.1007887107

- Naumann S, Kaphengst T, McFarland K, Stadler J (2014) nature-based approaches for climate change mitigation and adaptation. Bundesamt für Naturschutz. http:// ecologic.eu/sites/files/publication/2014/eco bfn nature-basedsolutions sept2014 en.pdf. Accession date: 20161007.

- $\quad$ Nehls T, Pfoser N, Puhr A (2010) Ungenutztes Flächenpotenzial für die Fassadenbegrünung am Beispiel Berlin. [Spare capacity of potential area for the façade greening - example of Berlin]. Fachvereinigung Bauwerksbegrünung e.V., Berlin, 42 pp.

- Norsys (2015) Netica Software. https://www.norsys.com/netica.html. Accession date: 2016122.

- $\quad$ Oke TR (1988) Street design and urban canopy layer climate. Energy and Buildings 11: 103-113. https://doi.org/10.1016/0378-7788(88)90026-6

- $\quad$ Peel MC, Finlayson BL, McMahon TA (2007) Updated world map of the Köppen-Geiger climate classification. Hydrology and Earth System Sciences Discussions 4 (2): 439-473. https://doi.org/10.5194/hessd-4-439-2007

- Pérez G, Rincón L, Vila A, González J, Cabeza L (2011) Green vertical systems for buildings as passive systems for energy savings. Applied Energy 88 (12): 4854-4859. https://doi.org/10.1016/j.apenergy.2011.06.032

- $\quad$ Perini K, Ottelé M, Fraaij AL, Haas EM, Raiteri R (2011) Vertical greening systems and the effect on air flow and temperature on the building envelope. Building and Environment 46 (11): 2287-2294. https://doi.org/10.1016/..buildenv.2011.05.009

- Pollino CA, Henderson C (2010) Bayesian networks: A guide for their application in natural management and policy. Landscape Logic technical report 48 (14): 48. URL: http://www.utas.edu.au/ data/assets/pdf file/0009/588474/

\section{TR 14 BNs a resource guide.pdf}

- Renterghem TV, Botteldooren D (2009) Reducing the acoustical façade load from road traffic with green roofs. Building and Environment 44 (5): 1081-1087. https:// doi.org/10.1016/.j.buildenv.2008.07.013

- Satterthwaite D (2006) Climate change and cities. Sustainable Development 1: 1-2. URL: http://pubs.iied.org/pdfs/11055IIED.pdf

- $\quad$ SenStadtUm (Ed.) (2011) Stadtentwicklungsplan Klima. [City climate development plan]. SenStadtUm, 79 pp. URL: http://www.stadtentwicklung.berlin.de/planen/ stadtentwicklungsplanung/download/klima/step klima broschuere.pdf 
- SenStadtUm (2014) Anteil öffentlicher Grünflächen in Berlin [share of public green in berlin]. http://www.stadtentwicklung.berlin.de/umwelt/stadtgruen/gruenanlagen/ index.shtml. Accession date: 2016510.

- $\quad$ Sheweka SM, Mohamed NM (2012) Green Facades as a New Sustainable Approach Towards Climate Change. Energy Procedia 18: 507-520. https://doi.org/10.1016/ j.egypro.2012.05.062

- Solecki WD, Rosenzweig C (2004) Biodiversity, Biosphere Reserves, and the Big Apple: A Study of the New York Metropolitan Region. Annals of the New York Academy of Sciences 1023 (1): 105-124. https://doi.org/10.1196/annals.1319.004

- Statistical Office (2015) Statistical Office Berlin-Brandenburg. https://www.statistikberlin-brandenburg.de/presse/presse pm.asp?

Sageb=120\&PTyp=100\&creg=BBB\&anzwer=2. Accession date: 2016802 .

- $\quad$ TEEB (2011) TEEB manual for cities. Ecosystem Services in urban Management. www.teebweb.org. Accession date: 2016510.

- Tzoulas K, Korpela K, Venn S, Yli-Pelkonen V, Kaźmierczak A, Niemela J, James P (2007) Promoting ecosystem and human health in urban areas using Green Infrastructure: A literature review. Landscape and Urban Planning 81 (3): 167-178. https://doi.org/10.1016/j.landurbplan.2007.02.001

- United Nations Environment Programme (2016) Building resilience of Ecosystems for Adaptation. http://www.unep.org/climatechange/adaptation/EcosystemBasedAdaptation/ tabid/29583/Default.aspx. Accession date: 20161007.

- Uusitalo L (2007) Advantages and challenges of Bayesian networks in environmental modelling. Ecological Modelling 203: 312-318. https://doi.org/10.1016/ j.ecolmodel.2006.11.033

- Wamsler C, Pauleit S (2016) Making headway in climate policy mainstreaming and ecosystem-based adaptation: two pioneering countries, different pathways, one goal. Climatic Change 137 (1): 71-87. https://doi.org/10.1007/s10584-016-1660-y

- Wamsler C, Brink E, Rivera C (2013) Planning for climate change in urban areas: from theory to practice. Journal of Cleaner Production 50 (1): 68-81. https://doi.org/10.1016/ j.jclepro.2012.12.008

- Wang H, Rish I, Ma S (2002) Using Sensitivity Analysis for Selective Parameter Update in Bayesian Network Learning. Technical Report SS-02-03, 8 pp. URL: http:// www.aaai.org/Papers/Symposia/Spring/2002/SS-02-03/SS02-03-005.pdf

\section{Supplementary material}

\section{Suppl. material 1: Questionnaire for Bayesian network analysis}

Authors: Sprondel, N.; Donner, J.; Mahlkow, N.; Köppel, J.

Data type: Questionnaire

Filename: Questionnaire_facade greening BN analysis_ Sprondel et al.pdf - Download file (311.40 kb) 